\title{
A tecnologia CRISPR-CAS9: da sua compreensão aos desafios éticos, jurídicos e de governança
}

\author{
The CRISPR-CAS 9 technology: from it's comprehension to ethical, legal and \\ governance challenges
}

\author{
Haide Maria Hupffer* \\ Juliane Altmann Berwig ${ }^{*}$
}

\section{Resumo}

A tecnologia CRISPR-Cas9 tem demonstrado as revoluções possíveis em razão da edição de genoma. Prevenção e tratamento de doenças, medicina genética corretiva, aprimoramentos genéticos e seleção/aumento de genes embrióticos são algumas de suas possibilidades. Nesse contexto, surgem inúmeros questionamento éticos, os quais solicitam a proteção dos preceitos jurídicos para o controle dos riscos dessa tecnologia revolucionária. Para tanto, neste artigo, objetiva-se apresentar a tecnologia, seus riscos e oportunidades, bem como demonstrar os possíveis caminhos para uma governança jurídica. A metodologia utilizada é a sistêmico-construtivista. Ao final do artigo, conclui-se que as discussões precisam ocorrer e que devem permitir o estabelecimento de uma comunicação entre os sistemas do Direito, da Ciência, da Economia e político, permitindo, assim, a ampliação do conhecimento sobre os riscos/oportunidades dessa tecnologia para, então, concretizar a governança com suporte na teoria do pluralismo jurídico.

Palavras-chave: CRISPR-Cas9. Desafios éticos. Direito. Governança.

\section{Abstract}

CRISPR-Cas9 technology has demonstrated possible revolutions due to genome editing. Disease prevention and treatment, corrective genetic medicine, genetic enhancements, selection / increase of embryonic genes, are some of its possibilities. In this context, innumerable ethical questions arise, which request the protection of the legal precepts for the control of the risks of this revolutionary technology. This article aims to present technology, its risks and opportunities, as well as to demonstrate the possible ways for a legal governance. The methodology used is systemic-constructivist. At the end of the article, it is concluded that the discussions must take place and such should allow the establishment of communication between the systems of Law, Science, Economics and Politics, thus allowing the expansion of knowledge about the risks l opportunities of this technology for then implement governance based on the theory of legal pluralism.

Keywords: CRISPR-Cas9. Ethical challenges. Law. Governance.

\section{Introdução}

O método CRISPR-Cas9 já provou ser revolucionário, despontando com imenso potencial para pesquisa e medicina genética. Sua precisão para leitura e para edição do genoma com baixo custo, considerando a tecnologia de edição genética, pode solucionar problemas genéticos de longa data, evitando-os. Para tanto, a tecnologia guarda inúmeras possibilidades de solução de problemas até então irreversíveis. Contudo os

Doutora em Direito e Mestre em Direito pela Unisinos. Especialista em Recursos Humanos e Graduada em Direito pela Unisinos. Graduada em Ciências Contábeis pela Fundação Machado de Assis agregada a PUCRS. Professora e pesquisadora no Programa de Pós-Graduação em Qualidade Ambiental e no Curso de Graduação em Direito da Universidade Feevale. Integrante do Núcleo Docente Estruturante do Curso de Direito. Líder do Grupo de Pesquisa Direito e Desenvolvimento (CNPq/Feevale). Líder do Projeto de Pesquisa "Novas Tecnologias e Sociedade de Risco: Limites e responsabilização pelo risco ambiental". Novo Hamburgo - RS - Brasil. E-mail: haide@feevale.br.

Doutora em Direito pela Universidade do Vale do Rio dos Sinos com Bolsa pela Coordenação de Aperfeiçoamento de Pessoal de Nível Superior (Capes) pelo Programa de Excelência Acadêmica (Proex). Mestre em Direito pela Universidade do Vale do Rio dos Sinos, especialista em Direito Ambiental Nacional e Internacional pela Universidade Federal do Estado do Rio Grande do Sul e graduada em Direito pela Universidade de Santa Cruz do Sul. Professora no curso de Direito da Universidade FEEVALE e Pesquisadora com o projeto "Os impactos humano-ambientais gerados pelas nanotecnologias: redesenhando os elementos estruturantes do direito ambiental". Novo Hamburgo - RS - Brasil. E-mail: julianeberwig@ feevale.br. 
inúmeros riscos quanto às possibilidades de "erro" são preocupantes, especialmente quanto aos aspectos éticos e, dessa forma, o seu controle jurídico no mundo global.

Diante desse tema, o presente artigo pretende responder ao seguinte problema: frente às oportunidades e aos riscos da tecnologia CRISPRCas9 quais seriam os possíveis caminhos jurídicos para a pesquisa e a inovação responsável?

Uma hipótese que se levanta é a de que é imprescindível que se reflita criticamente sobre os riscos do avanço irresponsável da técnica CRISPRCas9, haja vista que os problemas éticos, jurídicos e sociais que podem surgir com a aplicação em humanos são enormes, o que justifica um debate social amplo. Tal debate deve partir de uma contextualização global, na qual os preceitos jurídicos compreendam a pluralidade de fontes do Direito. Construindo, assim, um diálogo pela busca de uma governança global, ética e jurídica responsável frente às possibilidades ilimitadas da técnica CRISPRCas9.

A metodologia utilizada é a sistêmico-construtivista, possibilitando a observação dos sistemas do Direito, da Economia, da Ciência e político para averiguar as possíveis pontes de comunicação entre eles. Portanto, este artigo parte da caracterização da tecnologia CRISPR-Cas9 para, na sequência, explanar os riscos e caminhos éticos, jurídicos e de governança.

\section{Compreendendo o CRISPR}

O cientista chinês He Jiankui, da Southern University of Science and Technology, anunciou em vídeo no YouTube, no dia 25 de novembro de 2018, dois dias antes da realização da Second International Summit on Human Genome Editing, em Hong Kong, que ele e seus colegas "criaram" os primeiros bebês geneticamente alterados do mundo, Lulu e Nana. No seu discurso na conferência de Hong Kong, He Jiankui explicou detalhadamente sua experiência, informando que ele e sua equipe de pesquisadores recrutaram oito casais voluntários com as seguintes características: todos os participantes do sexo masculino deveriam ser HIV positivos e todos os participantes do sexo feminino HIV negativos. O "esperma dos participantes infectados com HIV foi 'lavado' para se livrar do HIV e, em sequência, foi injetado em óvulos coletados das participantes femininas". He Jiankui e sua equipe de pesquisadores utilizaram "uma repetição palindômica curta interespaçada (CRISPR-Cas9)", conhecida como uma técnica de edição de genes, e, em sequência, "desativaram um gene chamado CCR5 nos embriões, com o objetivo de fechar a porta proteica que permite que o HIV entre em uma célula, tornando os sujeitos imunes ao vírus HIV". Duas gestações foram bemsucedidas e uma delas resultou no nascimento das meninas gêmeas Lulu e Nana. Inicialmente, a imprensa chinesa descreveu a pesquisa como um grande avanço para a prevenção de doenças. Contudo, quando informações mais detalhadas foram reveladas, a comunidade científica internacional, bioeticistas, advogados e o público em geral condenaram fortemente a ação de He Jiankui, denunciando-a como antiética, com valor científico questionável, relação risco-benefício irracional, afronta e violação aos postulados éticos, revelando o fracasso do atual sistema de governança ética. (LI; WALKER; NIE; ZHANG, 2019).

O campo da engenharia do genoma cresceu rapidamente nas últimas décadas, o que permitiu a descoberta do sistema CRISPR-Cas9 em 2012 (WANG, 2017). Esse crescimento exponencial da edição de genomas tem colocado enormes desafios para a bioética. O experimento de He Jiankui com embriões humanos chocou a comunidade científica mundial e despertou os conselhos de ética em pesquisa, cientistas e profissionais para o abismo obscuro de experimentos arriscados em nome de avanços científicos, alertando que experimentos em embriões humanos, como o realizado por He Jiankui e sua equipe, poderiam impactar negativamente o futuro da humanidade (HIRSCH; IPHOFEN; KOPORC, 2019).

Antes de adentrar ao objetivo principal deste artigo, faz-se importante conhecer brevemente o histórico da tecnologia CRISPR-Cas9 (Clustered Regularly Interspaced Short Palindromic Repeats - Cas9 associated), ou "conjunto de repetições palindrômicas curtas, agrupadas e regularmente interespaçadas", que se diferencia por conciliar técnicas moleculares e biotecnológicas sofisticadas "para aplicação em edição genômica" e para "reconhecer a sequência-alvo a ser modificada no DNA", introduzindo modificações. O CRISPR-Cas9 já está disponível comercialmente para ser utilizado em diferentes organismos e diversos 
alvos genéticos, bem como para desenvolvimento de novas pesquisas pelas suas possibilidades criativas de aplicação (AREND; PEREIRA; MARKOSKI, 2017). É, portanto, uma "técnica de biologia molecular que em poucos anos se tornou protagonista de um avanço surpreendente na genética" (SBG, 2016).

O conceito de terapia gênica surgiu durante os anos 60 e 70, estando desde lá em constante crescimento (SANTOS et al. 2016). Em 1974, foi criada a técnica denominada TALEN (Transcription Activator-Like Effector Nucleases) para realizar a edição do DNA. Em sequência, no ano de 1975, ocorreu o Congresso Internacional sobre Moléculas de DNA Recombinante, na cidade de Asilomar, no estado da Califórnia, Estados Unidos. Desse congresso participaram cientistas e representantes da sociedade, o que motivou a "elaboração de normas de biossegurança e limites das pesquisas com DNA recombinante" (LAUXEN; GOLDIM, 2015, p. 203).

A busca pelo aperfeiçoamento da edição do DNA levou ao desenvolvimento da técnica ZFN (Zinc Fingers Nucleases). A tecnologia aprimorou o método TALEN e melhorou a precisão da edição de sequências de DNA manipuladas em laboratórios. A nova técnica apenas refinou o procedimento existente, de modo que não gerou maiores repercussões éticas, nem tampouco alterações nas regras de biossegurança LAUXEN; GOLDIM, 2015, p. 203).

Posteriormente ao método ZFN, já reconhecido como um avanço, o método CRISPR foi desenvolvido, sendo uma "técnica relativamente simples e precisa em termos de sequências editadas". Com características de maior precisão, as anteriores "tesouras genéticas" evoluíram para os "bisturis genéticos". Para realizar mutações peculiares, inicialmente foi "produzida uma proteína diferente para cada genoma a ser modificado. Posteriormente, a técnica foi associada à proteína 9, que resultou no sistema denominado CRISPR-Cas9, passando a utilizar a mesma proteína para os diversos genomas objeto de modificação" (LAUXEN; GOLDIM, 2015, p. 203).

A técnica CRISPRCas, em resumo, utiliza pequenos fragmentos de ribonucleic acid (RNA - também conhecido como ácido ribonucleico), que serve para "realizar a fragmentação de sequências específicas de DNA para a edição e inserção de novo gene na célula alvo" (MARÇAL; AMORIM, 2017, p. 59). Barcellos (2018, p. 15) compreende que a "alteração do gene CCR5 pela CRISPR, portanto, não é algo tão trivial assim como querem fazer acreditar, já que é, num certo sentido, também uma 'droga': a partir do mecanismo de defesa antigo e natural encontrado em diversas bactérias". Assim, o sistema CRISPRCas é baseado no "sistema imunitário das bactérias que as ajuda a proteger de fagos ou plasmídeos através da transferência de genes invasores" (SANTOS et al., 2016, p. 41), que foi objeto de estudo nos anos 1980 e resultou em repetições de sequências de DNA. (BARCELLOS, 2018, p. 15). O sistema foi descoberto, em 1993, por um estudante de pós-graduação espanhol, Francisco Mojica, que encontrou "cópias múltiplas de uma sequência repetitiva quase perfeita, aproximadamente palíndromica, de 30 bases" no micróbio Haloferax mediterranei. Ele cunhou, mais tarde, o termo "palindrómico curto clusterizado regularmente interse-repete", ou CRISPR (WANG, 2017).

Anos depois, os biólogos foram descobrindo o alcance da tecnologia CRISPR além do seu propósito biológico, a imunidade adaptativa, resultando no avanço, em 2012, ocorrido na Universidade da Califórnia, Berkeley (EUA), em que um grupo de pesquisadores vinculou a programabilidade da CRISPR com a proteína associada ao CRISPR, resultando no Cas9 (JINEK et al. 2012; WANG, 2017). Santos et al. (2016, p. 41) explicam a técnica de utilização dos vírus para o transporte dos genes:

Recentemente, os principais vetores utilizados para transportar os genes modificados para as células são os vírus. Estes ligam-se a uma célula hospedeira e transferem o seu material genético para o interior da mesma. Aproveitando esta característica peculiar dos vírus, os cientistas começaram a modificá-los. No entanto, é importante que o vírus mantenha a capacidade de infetar as células, dando a oportunidade do DNA benéfico ser inserido nas células hospedeiras.

Logo, de uma forma simples e genérica, a técnica do CRISPR-Cas9 pode ser pensada como um par de tesouras moleculares guiadas por um satnav (satellite navigation - satélite de navegação). A tesoura é uma enzima de corte de DNA. É cortado um ponto preciso no DNA da célula usando uma molécula guia personalizada, um único pedaço curto de RNA, o primo químico do DNA. A enzima de corte de DNA 
é conhecida como Cas9, portanto, a técnica é muitas vezes escrita CRISPR-Cas9. A edição do genoma ocorre quando a célula se apressa para reparar naturalmente a quebra feita pela tesoura. $O$ reparo da célula, muitas vezes, não é exato o suficiente para que o gene que foi cortado continue funcionando. Genes também podem ser corrigidos ou novos genes inteiros adicionados se um novo pedaço de DNA for incluído junto com o mecanismo CRISPR. Eles se corrigem durante o processo de reparo celular. (CORBYN, 2015).

Cientistas chineses, ultrapassando questões morais, anunciaram, no ano de 2015 , terem sido os primeiros a aplicarem o CRISPR-Cas9 na edição de genes de embriões humanos (LIANG et al., 2015) e a modificarem geneticamente "células embrionárias utilizando a técnica por CRISPR-Cas9". A mesma aplicação foi repetida, como já registrado, por outro grupo de pesquisadores chineses, liderados por He Jiankui, que relataram avanços ao "conferir resistência ao HIV pela inserção da mutação do gene CCR5. A análise genética mostrou que 4 dos 26 embriões foram modificados com sucesso" (GONÇALVES; PAIVA, 2017, p. 373-4). No entanto, usar o CRISPR-Cas9 para modificar genes humanos desencadeou preocupações éticas e morais sobre o impacto dessa tecnologia na evolução humana e suas implicações na busca pela fabricação de "bebês designers". Além disso, permanecem muitas incógnitas sobre a tecnologia CRISPRCas9 e sobre as consequências inesperadas na edição de genes e como poderão repercutir nas gerações futuras (XU, 2020).

Note-se que, em 2015, os pesquisadores chineses editaram os genes de um embrião humano em laboratório alarmando a comunidade científica e provocando protestos globais para que a técnica não fosse aplicada em bebês. Entretanto, como já referenciado, em 2018, a invenção do CRISPR, poderosa ferramenta de edição de gene, fácil e barata para implantar, deu asas para o nascimento de seres humanos geneticamente modificados em um centro de fertilização in vitro na China. Documentos médicos postados em novembro de 2018 por uma equipe da Southern University of Science and Technology, de Shenzhen, indicam que estavam recrutando casais para desenvolver a primeira gene-edição em bebês, ou seja, embriões modificados geneticamente e transferidos para o útero da mulher, livres de HIV. A promessa é eliminar o gene CCR5 de proles resistentes ao HIV, cólera e varíola. Nos dados apresentados na metodologia experimental realizada está descrito que os experimentos foram realizados em fetos de até 24 semanas (6 meses). Depois da publicação da matéria, foi divulgado um vídeo institucional pelo professor Universitário He Jiankui sobre o nascimento das duas meninas gêmeas, primeiros humanos geneticamente adaptados, como uma das principais conquistas da medicina (REGALADO, 2018).

Sair dos laboratórios de pesquisa "in vitro" para pesquisa "in vivo", testando, inicialmente, em modelos animais para aprimorar a técnica e, em sequência, partir para aplicar em embriões foi o passo dado, no final do ano de 2018, pelo professor Universitário He Jiankui, que alterou o DNA, provocando uma mutação genética nas gêmeas nascidas para que elas se tornassem resistentes ao vírus HIV, ou seja, impedindo que elas desenvolvessem HIV ao eliminar a doença. Dado o poder do método CRISPR-Cas9, a complexidade ética sobre a intervenção humana no DNA, os crescentes alertas da comunidade científica e médica sobre a responsabilidade ética da pesquisa, o potencial inquestionável para o tratamento de doenças e avanços em diversos setores, questiona-se: não se está desenvolvendo uma nova forma de eugenia dos adaptados geneticamente pela tecnologia e de uma classe econômica com condições financeiras para assumir os custos da terapia gênica?

O método CRISPR-Cas9 provou ser revolucionário, despontando um imenso potencial para a pesquisa e a medicina, com uma incrível precisão para leitura e para editar o genoma e com baixo custo para uma tecnologia de edição genética. É uma conjectura interessante que se apresenta: combina baixo custo, fácil programabilidade, ampla aplicabilidade e alta especificidade, abrindo, assim, o caminho para uma verdadeira revolução genética. Existem muitas possibilidades de aplicação: no tratamento de doenças, em aprimoramentos genéticos, na seleção/aumento de genes embrióticos nos chamados "bebês projetados", entre muitas outras possibilidades (WANG, 2017).

Kits com CRISPR-Cas9 já são fornecidos por uma "organização sem fins lucrativos chamada Addgene, localizada nos Estados Unidos" que os despacha para as mais diferentes partes do mundo pelo correio diariamente, o que significa que "em princípio, qualquer pesquisador, ou até mesmo estudantes de biologia 
com conhecimentos razoáveis de genética, e acesso aos reagentes e equipamentos necessários, já podem realizar experimentos que envolvem a modificação do código genético de um organismo". (ARAÚJO, 2016).

As vantagens do sistema relacionam-se com a alta versatilidade, eficácia, especificidade e facilidade de uso. Expondo isto, organizações farmacêuticas e investigadores na área da biotecnologia têm trabalhado de modo a proporcionar uma oportunidade excepcional para a comunidade científica para realizar a sua aplicação na "terapia de células humanas, como a terapia genética, correção de defeitos em genes de células progenitoras, doenças genéticas, tratamento do cancro e mesmo do HIV, HPV e EBV em células infetadas, bem como estratégias de melhoramento de perturbações genéticas". Também, o sistema tem demonstrado ser uma "técnica bastante eficaz na eliminação dos vírus das células infetadas e na cessação dos tumores" (SANTOS et al., 2016, p. 43).

As células editadas são devolvidas na esperança de criar uma população de células $T$ resistentes ao HIV que possam combater o vírus. Assim como com Crispr, as ZFNs personalizadas, que vêm como um par onde uma estrutura de proteína contendo moléculas de zinco orienta, cortam o DNA em um local preciso - o gene CCR5 - antes que o processo de reparo natural, mas impreciso, da célula entre em ação, nocauteando o gene. Isso realmente ilustra o poder da abordagem para tratar doenças (CORBYN, 2015, p. 1).

Um desafio da tecnologia CRISPR-Cas9 é "como obter o gene - ou o mecanismo Crispr - dentro das células". Os métodos que "estão sendo adotados a partir da terapia genética para encapsular e distribuir variam de vírus modificados a nanopartículas. Todos ainda estão longe de serem perfeitos" (CORBYN, 2015).

Descobriu-se que as doenças genéticas perseveram através das gerações, sendo incapazes de serem "removidas" naturalmente. Por isso, o CRISPR poderá contribuir para o processo seletivo genético, preenchendo a lacuna, reduzindo o abismo entre os grupos geneticamente desfavorecidos e os saudáveis (WANG, 2017).

Logo, as aplicabilidades da técnica são diversas. Atualmente, inúmeros projetos no mundo se encontram em andamento. O CRISPR já está beneficiando muito o mundo, mesmo existindo há meia década, e a pesquisa subsequente só irá refiná-lo, avançando ainda mais em novas possibilidades de terapias. Milhares de doenças genéticas poderão ser erradicadas (daltonismo, doença de Huntington, entre muitas outras). Uma forma potencial de terapia é o tratamento de células somáticas ou não reprodutivas. Nisso, os cientistas já demonstraram avanços significativos. Além disso, como alternativa ao diagnóstico genético préimplantacional, a terapia gênica poderia salvar um embrião que, de outra forma, seria jogado fora (WANG, 2017).

A ampla gama de efeitos moleculares (ativação/repressão gênica, substituição alélica, clivagem de DNA/RNA, deleção de genes, knock-in/out, inserção de transgenes, geração de variação genética, etc.) e abordagens possíveis (DNA labeling, mapeamento gênico, RNA tracking, etc.) por meio de CRISPR se traduz em uma miríade de possibilidades para a ciência, tecnologia e mercado.[...] CRISPR também tem sido utilizada na identificação de efeitos de certo gene em uma determinada patologia. Neste caso, os pesquisadores utilizaram CRISPR para gerar linhagens knockout deste microrganismo para o gene da enzima leucina aminopeptidase. [...] Identificação e validação de novos alvos terapêuticos e bloqueio à entrada de vírus. Potencial de CRISPR em estratégias para o controle do crescimento tumoral e, consequentemente, aumentar a expectativa de vida dos pacientes. Terapia Gênica ( PASSOS et al., 2016, p.72-76.).

Foi publicado na Revista Scientific Reports um estudo realizado pelos pesquisadores da Universidade da Califórnia apresentando outra possibilidade de aplicação do CRISPR, para avanços no tratamento do carcinoma metastático de células renais. A Revista Nature compartilhou o artigo em sua página virtual (SCHOKRPUR et al. 2016). Em outro estudo, liderado por pesquisadores da Universidade Federal da Bahia, a técnica poderia melhorar o diagnóstico de patógenos em uma contaminação bacteriana e viral no ponto de atendimento de forma rápida e com baixo custo (BATISTA; PACHECO, 2018).

O CRISPR permite, assim, a precisa e fácil manipulação do DNA no núcleo de qualquer célula, sendo possível realizar manipulações no "espermatozoide, no óvulo ou em um embrião de uma célula", que está prestes a começar a replicar o seu DNA, e elas podem se tornar permanentemente "seladas na 
chamada linhagem germinativa, para serem herdadas pelas gerações futuras". Essa perspectiva aumenta a possibilidade de gerar descendentes que não trazem risco ou reduzir o risco de algumas doenças genéticas. Um dia seria possível corrigir uma mutação prejudicial em determinado gene e impedir que alguém herde a predisposição ao câncer de mama (CORBYN, 2015).

As perspectivas apresentadas são muito promissoras para a criação de novos mercados para empresas farmacêuticas, medicina personalizada, comunidade científica, área da genética, biotecnologia, bioengenharia, entre outras áreas. Terá impacto nos Direitos Humanos e sobre escolhas individuais. É possível prever que é muito difícil manter os avanços já divulgados pela ciência com a técnica CRISPRCas9 no campo de visão dos cuidados éticos para com o ser humano. De igual forma, frente às escolhas individuais, é preciso questionar: se é proibido colocar em risco a sobrevivência das futuras gerações, você seria capaz de erradicar doenças genéticas de seus descendentes sem ser responsabilizado pelos riscos intergeracionais? É permitido eticamente usar todos os recursos para gerar embriões melhorados geneticamente e sem perturbações genéticas? Com esses questionamentos, buscar-se-á, na sequência, refletir criticamente sobre os riscos do avanço irresponsável da técnica CRISPRCas9.

\section{Riscos da técnica CRISPRCas9}

Vale ressaltar que a técnica CRISPRCas9 é uma revolução tecnológica com potencial para introduzir grandes mudanças científicas, sociais, econômicas, éticas, jurídicas e para novos formatos de governança de seus riscos. Além de levar em conta as justificativas fundamentais para os inúmeros benefícios do CRISPRCas 9 já propagados, também devem ser questionados criticamente os riscos da intervenção biotecnológica sobre o melhoramento genético, a biossegurança, a bioproteção das gerações presentes e futuras, o duplo uso da tecnologia, ou seja, utilizá-la para o bem e para o mal, e a falta de consenso na comunidade cientifica sobre os limites de sua utilização. Colocar as gerações presentes e futuras, qualquer ser vivo, em risco, entre outras questões, não pode ser considerado apenas como triviais pretensões tecnológicas de seus criadores. Essas "pontas soltas", como o desconhecido e o temor de riscos invisíveis, transtemporais e que podem ser irreversíveis para o futuro da humanidade, levam a questionamentos e colocam cientistas, governos e a sociedade em alerta, e, portanto, devem ser consideradas.

Por tais razões, discutir os riscos da técnica CRISPRCas9, mesmo diante de tantas oportunidades de maximizar o bem-estar da humanidade e eliminar inúmeras enfermidades, é um dever ético. McConnell e Blasimme observam que qualquer alteração genômica causa inquietações e divergências, pois o gene modificado se propagará às gerações futuras, o que tem provocado acirrados debates no campo da ética, da governança e no uso responsável da técnica. Para os autores, deve-se ir além do imperativo da inovação clínica e prestar atenção aos direitos humanos e à dignidade, considerando cuidadosamente as consequências para as pessoas com genes editados e possíveis reflexos às gerações futuras, tanto em termos de segurança quanto de prováveis usos eugênicos dessa tecnologia (MCCONNELL; BLASIMME, 2019).

Sugarman (2015), ao falar sobre os argumentos contrários - que buscam justificação no fato de i) ser inviável fornecer consentimento intergeracional, ii) ser impossível prever as consequências e iii) que essas manipulações representam uma séria ameaça à dignidade humana -, coloca que esses argumentos não estão se mostrando suficientes contra o uso da técnica.

Para Goldim (2015), a questão-chave nas discussões é a irreversibilidade quando se ultrapassa os limites éticos com a "introdução de novos recursos no pool genético". O autor observa que o CRISPR tem sido cada vez mais utilizado, mas sem uma reflexão aprofundada e interdisciplinar sobre suas implicações na dignidade humana, justiça, respeito às pessoas, responsabilidade retrospectiva e para com as gerações futuras. Essa é a razão para Goldim (2015) dizer que a técnica CRISPR é um dos desafios mais importantes apresentados pela ética e pela pesquisa genética.

Corbyn (2015) relatou a pesquisa de um cientista chinês que fez uso da técnica CRISPR para a edição genômica de embriões humanos utilizando 86 embriões desenvolvidos para fins de reprodução assistida, que tinham sido descartados por serem considerados inviáveis. Na aplicação relatada, o objetivo era "corrigir 
o defeito genético que causa o distúrbio sanguíneo beta-talassemia e os embriões não viáveis, que não poderiam ter resultado em nascidos vivos". Tal fato preocupa muitos cientistas, dado o potencial do CRISPR de modificar os seres humanos. Existem características genéticas que aferem "ossos extra-fortes, baixo risco de Alzheimer ou resistência viral, como ao HIV". Isso remete ao pensamento de que o método poderá criar seres humanos melhores ou aprimorados, e não apenas eliminar de forma preventiva as doenças detectadas. "O que dizer de melhorias como viver mais, melhorar a cognição ou alterar os atributos físicos?" Por outro lado, esses traços multigenéticos seriam difíceis de editar, visto que não se sabe com precisão a base deles e as consequências não intencionais resultantes. (CORBYN, 2015).

O sistema CRISPR-Cas9 traz uma série de preocupações de ordem ética e social, os quais levaram os cientistas a recomendar "uma moratória da introdução de modificações hereditárias no genoma humano", motivada pela preocupação de que a técnica pode possibilitar a criação de "bebês por medida, gerar edições de genoma potencialmente arriscadas ou eliminar ecossistemas inteiros". Se utilizado para controlar pragas, o CRISPR "pode provocar efeitos ou mutações imprevistas, que podem ocasionar a dispersão do impulsionador genético e o desaparecimento de toda uma população de animais, fugas acidentais e/ou a perturbação irreversível de ecossistemas inteiros", razão pela qual o Parlamento Europeu, em 2017, divulgou que CRISPR-Cas9 está entre as "dez tecnologias suscetíveis de transformar as nossas vidas" e chamou a atenção para o princípio da não meleficência na avaliação de riscos, que deve ser considerada na tomada de decisão em relação à utilização da técnica (PARLAMENTO EUROPEU, 2017, p. 31).

Os principais argumentos que sustentam, de acordo com Bergel, a oposição à terapia gênica na linha germinal são os seguintes: "i] os riscos para os indivíduos; ii] a afetação à sacralidade do genoma; iii] o risco de uma 'nova eugenia'; iv] terapia gênica em células somáticas; v] as intervenções de 'melhora' e a edição genética” (BERGEL, 2017).

O primeiro deles, "riscos para os indivíduos", está relacionado à existência de forte incerteza científica quanto aos efeitos da aplicação da técnica CRISPR nos seres humanos. Diante disso, aplica-se o princípio de precaução para desqualificar a aplicação de técnicas de engenharia genética e "para alguns, essa invocação constituiria razão suficiente para descartá-la". Quanto ao segundo, "a afetação à sacralidade do genoma", sendo o genoma humano inviolável, não pode ser objeto de manipulação nenhuma (BERGEL, 2017).

A Declaração sobre Genoma Humano e Direitos Humanos, determina, no artigo $1^{\circ}$, que "o genoma humano constitui a base da unidade fundamental de todos os membros da família humana, bem como de sua inerente dignidade e diversidade", que simbolicamente significa "o patrimônio da humanidade". O artigo $11^{\circ}$ determina que não devem ser permitidas quaisquer práticas que sejam contrárias à dignidade humana; e, no artigo $12^{\circ}$, letra "a" assevera que toda pessoa deve ter acesso aos progressos da biologia, da genética e da medicina em matéria de genoma humano, respeitando sua dignidade e seus direitos. Contudo na letra "b" do artigo 12 é assegurada a "liberdade de pesquisa necessária ao avanço do conhecimento" indicando ainda que "as aplicações da pesquisa, incluindo aquelas realizadas nos campos da biologia, da genética e da medicina, envolvendo o genoma humano, devem buscar o alívio do sofrimento e a melhoria da saúde de indivíduos e da humanidade como um todo". (UNESCO, 1997).

O terceiro ponto mencionado, "o risco de uma 'nova eugenia", e se refere aos discursos de que a pesquisa estaria relacionada à metáfora da "criação de humanos" (UNESCO, 1997). Bergel (2017), em seu artigo sobre os impactos éticos, defende o posicionamento de que falar de eugenia seria avançar muito além da técnica.

Ainda que seja possível que utilizando técnicas de engenharia genética possam aparecer situações que lidam com o que Habermas chama de "eugenia liberal", acredita-se que a generalização acarreta um pessimismo desmotivado, como se fosse um problema inacessível o de colocar limites à utilização desviada dessas técnicas, incluindo agora à edição do genoma humano com a técnica CRISPR/ CAS 9. Falar de eugenia nesse panorama é ir muito longe na via de argumentar contra a utilização desviada dessas técnicas (BERGEL, 2017, p. 457).

Entretanto deve-se ter presente que Habermas (2004, p. 43), ao alertar sobre a possibilidade de a humanidade estar caminhando para uma eugenia liberal, é claro em revelar que pode haver conflitos na proteção da vida do feto, principalmente, se for considerado que muitos pais escolhem ter um filho como 
se "fosse um bem material", e esse desejo pode levar a recusarem a "implantação se o embrião não corresponder a determinados padrões de saúde". É um grande conflito ético que se instala, em especial, conforme Habermas (2004, p. 43), "nesse conflito, os pais não são envolvidos de improviso; eles aceitam desde o princípio o embate ao mandarem fazerem exame genético do embrião". O autor, ao instigar uma discussão crítica e ética, quer chamar a atenção ao mencionar que "esse tipo de controle deliberado da qualidade coloca um novo aspecto em jogo - a instrumentalização de uma vida humana, produzida sob condições e em função de preferências e orientações axiológicas de terceiros". A respeito desse aspecto, certamente frente ao diagnóstico de uma doença grave e genética, "a decisão de seleção orienta-se pela composição desejada do genoma. Uma decisão sobre a existência ou a não-existência se dá conforme o critério da essência potencial" (HABERMAS, 2004, p. 43).

A preocupação também é compartilhada pelo Parlamento Europeu (2017), quando da discussão realizada sobre a utilização da técnica CRISPR-Cas9 com objetivos de aperfeiçoar o ser humano, ao se posicionar de modo que a tecnologia pode causar danos irreversíveis para as gerações futuras com a apropriação irresponsável de um território até agora inexplorado. Entre outros riscos apontados, sobressai o "receio de se estar a abrir a porta a novas formas de desigualdade, discriminação e conflito sociais, bem como a uma nova era de eugenia". (PARLAMENTO EUROPEU, 2017, p. 31), razão pela qual se deve ter cuidado.

Além de livrar o embrião de doenças genéticas, seria possível melhorar artificialmente certas características. Ao criar esses "bebês estilistas", se teria o poder de "aumentar as habilidades físicas da criança, melhorar sua inteligência, e selecionar fenótipos específicos que são considerados desejáveis" (WANG, 2017, p. 7). Seria uma forma de eugenia liberal para uma classe social que tem recursos para realizar o sonho de ter uma prole perfeita, o que pode ser observado no dizer de Jacquard e Kahn (2004, p. 32): "é impossível que a humanidade inteira, que conta com mais de seis mil milhões de indivíduos, possa evoluir geneticamente em conjunto! Uma mutação genética, ou uma selecção particular, não pode difundirse em toda a Terra, já que hoje em dia somos demasiado numerosos".

Da mesma forma, é plausível que o CRISPR-Cas9 poderá exacerbar um futuro opressivo para os mais desafortunados e para Estados com crescentes disparidades econômicas, deixando para o destino a genética das pessoas mais modestas, ou criando o que poderia resultar em um exército hierárquico de seres melhorados com a tecnologia e seres que não têm acesso à tecnologia. (BROKOWSKI; POLLACK; POLLACKC, 2016).

Um argumento contra o aprimoramento genético é a ideia de que uma criança perde autonomia, ou o "direito a um futuro aberto". Com isso, as crianças não teriam a liberdade de escolha se seus pais Ihes predeterminarem certos talentos e habilidades. Além disso, há um grau de educação, como oposição à natureza, no desenvolvimento de uma criança. Certamente não é o caso hoje em dia, pois as crianças têm controle total sobre seus valores, opiniões e até hobbies. Muito disso é suscetível aos fatores sociais, políticos e ambientais de como as crianças são criadas. (WANG, 2017).

Wang (2017, p. 9) mostra que pesquisadores compreendem que a técnica permite alterar ou aumentar determinadas características, tais como: "traços como atletismo, características físicas, inteligência, habilidade artística" Como sociedade, é importante aderir à ideia do "aprimoramento" com cautela, sendo prudente evitar uma nova forma de "eugenia liberal", permitindo, ainda, a regulamentação e restrição de melhorias. Wang (2017, p. 9) acredita que "com tudo isso em mente, podemos confiantemente proceder para o futuro de engenharia do genoma, onde um ousado mundo novo nos aguarda".

Quanto à "terapia gênica em células somáticas", que "consiste em corrigir ou melhorar um estado patológico por transferência de material genético em um órgão ou tecido, excluindo as células germinais" (BERGEL, 2017, p. 458), recomendações estipulam limites éticos para o seu uso:

Usar os processos regulatórios existentes sobre terapia gênica humana para conduzir a pesquisa e os usos sobre edição do genoma humano somático;

Limitar as provas clínicas ou terapêuticas aos tratamentos de prevenção de doenças ou inabilidade; Avaliar a segurança e a eficácia no contexto de risco e benefício do uso pretendido;

Demandar uma ampla opinião pública favorável antes de estender seu uso. (BERGEL, 2017, p. 459). 
No quinto ponto, "as intervenções de 'melhora' e a edição genética", o conceito prevalecente quanto às intervenções restringia-se à ideia de doença (BERGEL, 2017, p. 460). Todavia o próprio conceito de doença pode ter diferentes nuances:

[...] existem casos nos quais a doença como conceito confrontado ao normal pode ser claramente distinguível (v.g. enfermidades monogênicas), enquanto em outros casos a distinção passa pela construção social. Se definitivamente admite-se a terapia gênica - seja em células somáticas ou na linha germinal - se imporia uma regulação que contribua a delimitar critérios. Ficariam à margem situações confusas que exigem um maior nível de exatidão, mas apesar das dificuldades que possam implicar essa tarefa, não se pode converter em um obstáculo insuperável (BERGEL, 2017, p. 459).

Bergel (2017, p. 460) continua na mesma linha de sua argumentação citada, mencionando que "as intervenções de melhora sobre o genoma humano no estado atual da ciência constituem uma fantasia que pode servir muito mais para alimentar a literatura do que para preocupar aos homens de ciência", haja vista que a multiplicidade de fatores genéticos que determinam uma aptidão/capacidade humana está ligada à intervenção de fatores ambientais (tomados em um sentido amplo) e sociais, o que posicionaria os cientistas num possível foco difícil de atender, se fosse esse o caso. Todavia o pesquisador reafirma que "a simples possibilidade de futuro que pode existir faz que antecipadamente se acendam as luzes de alarme". Esse alarme estaria relacionado com a impossibilidade da interação da terapia gênica na linha germinal, para a conservação do genoma não manipulado e a proteção das gerações futuras. "Numa posição menos categórica alguns preveem a possibilidade das terapias em linha germinal, com cuidados extremos". Os debates estão longe de se terem concluídos, especialmente quando se fala em "diagnóstico pré-implantatório e as intervenções sobre embriões humanos". (BERGEL, 2017, p. 456).

Essa tensão entre os riscos e benefícios da livre manipulação da natureza humana deveriam pautar as discussões éticas sobre os princípios que guiam o CRISPR-Cas9 e quais deveriam ser esses valores. Outra questão posta e de difícil resposta frente à fragmentação da sociedade global está em questionar quem deveria lidar com as questões éticas da manipulação da natureza humana, tanto para fins de terapia gênica como para decidir se os embriões que apresentam alterações gênicas poderiam ser livremente descartados.

Há que se ter uma governança responsável para a técnica CRISPR-Cas9 e outras desenvolvidas ou ainda nem sonhadas, que podem impactar na essência do que se conhece por ser humano. O Direito, a Ética e a Bioética não podem ficar indiferentes frente à possibilidade de, em um futuro não muito distante, determinado Estado ou grupo econômico decidir qual o "tipo" e qual o "perfil" de ser humano que querem para determinado período histórico cultural e quais os limites para decidir quem não pode nascer por não estar apto pelo olhar do sistema econômico, social e da ciência. Assim, na sequência, a intenção é iniciar um diálogo em busca de uma governança ética e jurídica responsável frente as possibilidades ilimitadas da técnica CRISPR-Cas9.

\section{Por uma governança e ciência responsável}

Governança responsável transcende o campo da Engenharia genética, Medicina, Biotecnologia, Economia e política, e passam a exigir que os limites da ciência sejam refletidos em outros campos de saberes, como a Ética, a Bioética e o Direito. Retomando o início do presente estudo, o caso das modificações genéticas dos dois bebês pelo médico e professor chinês He Jiankui, que usou a técnica de edição de gene CRISPR, questiona-se: e se o experimento desse errado?

O efeito colateral da "manufatura médico-tecnológica da vida humana" é nominado por Beck como metamorfose, ou seja, são as consequências não desejadas dos avanços da tecnociência e que escapam às tentativas de regulação. Quando o início da vida e seus fundamentos antropológicos estão sendo "reconfigurados pela porta dos fundos dos efeitos colaterais do sucesso da medicina reprodutiva", a moralidade e a ética fracassam e abrem espaço para a valoração da "maleabilidade pré-natal da condição humana". A metamorfose, segundo Beck, destrói as certezas antropológicas que sustentam o início da vida e "põe as instituições existentes sob enorme pressão para agir através de alternativas práticas novas, antes inimagináveis". Jargão tecnológico sobre embriões como "controle de qualidade de embriões" e 
"armazenamento de embriões" não podem ser desconsiderados, pois "envolve seleção pré-natal" e a possibilidade de "destruição de vida humana futura" (BECK, 2018, p. 43-52).

Jonas (2013, p. 206-207) reflete que, neste momento, a intenção é ainda de cura "dos futuros indivíduos e de sua descendência", o que representa uma intenção corretiva. O problema se apresenta quando o desejo é o de alterar um dado DNA "mediante acréscimo, exclusão e rearranjo de elementos - uma reescritura, por assim dizer, do texto genético", que torna possível sua leitura. O alerta de Jonas (2013, p. 207) é no sentido de que é possível criar "novos tipos de seres vivos, 'aberrações' intencionalmente criadas e linhagens inteiras a partir delas". Essa aventura carrega consigo o potencial de uma "ruptura metafísica com a essência normativa do homem". Frente a total imprevisibilidade das consequências das apostas na engenharia da biologia molecular, o ser humano poderá estar renunciando a sua integridade e criando um novo tipo de sociedade que deverá absorver ou descartar as malformações não desejadas. Em sua crítica, Jonas (2013, p. 208) estima que "a atrofia de certas propriedades, a hipertrofia de outras, a edição de novas ainda, resultará em uma crescente adequação para certas tarefas de um mundo tecnológico".

O mais angustiante na percepção de Jonas (2013, p. 209) é poder jogar fora o que foi criado com um propósito quando ele não mais serve para o propósito desejado ou, ainda, quando o propósito não mais existir. No dizer de Jonas, pode-se refletir sobre a "fábrica de embriões" e a "indústria de reprodução humana" sobre as quais Beck (2018, p. 49) escreve anos depois. De igual forma, Jonas (2013, p. 209) alerta que, se a humanidade se acostumar com o hábito da "disposição utilitária" de embriões, "não haverá então como dizer onde e por quais princípios não utilitários ela deve parar". E é aí que Jonas questiona: "que direito superior o produto natural pode reivindicar em relação ao produto artificial?" Respondendo à questão, o autor chama a atenção para a "descarada concepção utilitária e o fantasma do super-homem como fim em si mesmo", que está presente no sonho de muitos cientistas "nesta zona crepuscular da ciência". As reflexões de Jonas (2013, p. 2010) se movem nas fronteiras do humano e as possibilidades da ciência diante da "bandeira da ciência pura e da livre pesquisa" e do livre jogo criativo.

Nesse ponto, é perceptível que a ascensão da engenharia genética é tema de debates na área das Ciências da Vida, os quais se centram em proteger a pesquisa e a inovação de suas eventuais utilizações indevidas por atores desconhecidos e imprevisíveis (RYCHNOVSKÁ, 2016). Também são questionadas formas de regulação, em especial, se é possível regular com restrições legais o avanço da engenharia genética para impedir que sejam violados os direitos humanos fundamentais, direitos da personalidade, direitos sobre o patrimônio genético humano, riscos potenciais e efeitos colaterais desse campo de pesquisa para as presentes e futuras gerações.

Rychnovská (2016) descreve que, para salvar o campo de restrições legais, no ano de 1975, cientistas concordaram voluntariamente em elaborar diretrizes de segurança relacionadas à pesquisa de DNA recombinante na Conferência Internacional em Asilomar. Essa conferência é considerada um símbolo do consenso científico e da capacidade da ciência de se autogovernar. Como resultado, práticas de autorregulação e avaliação de riscos foram introduzidas nas Ciências da Vida, alicerçadas na linguagem da ética científica e responsabilidade social.

Observa-se que a metodologia CRISPRCas9 inaugura um novo paradigma na história da evolução humana ao derrotar a evolução genética, que sofreu sérios revezes com o avanço da medicina reprodutiva. Criou-se um ambiente para evitar que o ser humano não morresse em função de sua genética. Síndromes e enfermidades que levavam o ser humano à morte, por não haver interferência e seleção no seu genoma, são agora salvos e capazes de se reproduzirem com a técnica de terapia gênica. Era o início da culturização à Biologia, à terapia gênica e à medicina reprodutiva. O CRISPRCas9 surge nesse cenário e se impõe por não apenas causar uma mutação em um gene-alvo, mas por avançar em relação às metodologias anteriores e conseguir fazer a edição de regiões específicas no DNA que, em síntese, significa a possibilidade de corrigir algumas doenças com origem genética (ROMÁN, 2017).

Wang (2017, p. 5), ao refletir sobre as discussões relativas aos aspectos éticos e jurídicos da técnica CRISPR, questiona: "por que a hesitação em direção ao seu acolhimento? Por que as pessoas temem o futuro da revolução genética?”. Ademais, de forma clara, o “CRISPR está causando impacto nos laboratórios 
em todo o mundo, mas o que isso implica para a sociedade? Como isso vai mudar a vida da pessoa média?" (WANG, 2017, p. 3).

As questões levantadas por Román (2017) são mais difíceis de responder e envolvem a ingerência humana no processo da evolução do ser humano. $O$ autor levanta questionamento sobre um futuro que interessa e afeta a todos, a saber: a evolução da espécie humana. Com esse dizer elabora as seguintes perguntas: se cientistas decidirem que autismo é uma enfermidade e deve ser eliminado, questiona-se se o autismo é uma enfermidade? Por que devemos modificar o ser humano no sentido indicado pelos pesquisadores e não em outro sentido? As melhoras genéticas que a técnica do CRISPR/Cas9 pode proporcionar são um reflexo da atual sociedade em se vive? A quem beneficiam? E se venderam para o mercado? Frente à incerteza científica, os potenciais riscos e o abismo que permeia esse novo paradigma da técnica genética CRISPRCas9, Román (2017) instiga que é chegada a hora de retomar o barco da Biologia, da engenharia genética e da medicina reprodutiva e usar o microfone para exigir responsabilidade da ciência.

É de especial importância para avançar na presente discussão ter presente o que Barcellos (2018, p. 15) anuncia sobre o CRISPR: é um elemento do "sistema imunológico bacteriano que mantém partes de vírus perigosos ao redor para poder reconhecer e se defender funcionando, e de certa maneira, funciona como um fármaco, remédio ou filtro e é essa qualidade de antissubstância que merece ser questionada pela filosofia". De igual forma, não se pode fechar os olhos para o fato que o descobrimento dessa técnica "abre importantes horizontes para a pesquisa científica" (BERGEL, 2017), pois se apresenta como uma "perspectiva futura para a possível cura de diferentes doenças e para a minimização de seus efeitos deletérios" (MARÇAL; AMORIN, 2017, p. 59), além de possuir o potencial de, até mesmo, alterar características humanas (LAUXEL; GOLDIM, 2015).

Logo, essa tecnologia genética pode representar uma evolução extraordinária para a solução e prevenção de futuras doenças desde o embrião, mas se manipulada de forma disruptiva negativa poderá incorrer em consequências inesperadas. Por isso, os "problemas éticos, jurídicos e sociais que podem surgir com a aplicação em humanos são enormes, o que justifica um debate social amplo" (BERGEL, 2017). Os aplicadores do Direito mencionam ser de suma importância conhecê-la bem, visto que "em breve poderão se debruçar em determinados casos concretos quanto à sua futura aplicação (ou não), de modo a garantir a solução de conflitos e a soberania do Estado Democrático do Direito amparado pelas normas jurídicas brasileiras que possam versar sobre o tema proposto" (MARÇAL; AMORIN, 2017, p. 59).

Lauxen e Goldim (2015, p. 220) compartilham sobre a necessidade de construir "diretrizes no sentido de recomendar, permitir, obrigar, desencorajar e/ou proibir técnicas de interferência genética, de acordo com o potencial de abrangência das tecnologias". Como essas questões são "relacionadas às intervenções na vida e na saúde humana" é imprescindível a participação nas reflexões de organismos internacionais e entidades nacionais como as que representam médicos e hospitais, comitês e conselhos de ética e de bioética, conselhos profissionais, instituições de ensino e de pesquisa, poder legislativo, executivo, judiciário e sociedade civil.

Como a ciência ainda não tem respostas, Sugarman (2015) aponta para uma ampla discussão pública para que cientistas, médicos, bioéticos e partes interessadas, com interesses legítimos e conhecimento suficiente, possam se envolver em um processo justo para auxiliar a garantir a integridade, não só dos processos, mas também dos resultados. As preocupações com a segurança e a falta de consenso político e ético sobre essa tecnologia são legítimas e isso passa a exigir mecanismos de fiscalização e supervisão. Entretanto o autor coloca que os atuais mecanismos de supervisão, como os comitês de ética de pesquisa e os comitês de supervisão de pesquisas com células-tronco, não são adequados e não estão preparados para realizar uma supervisão segura (SUGARMAN, 2015).

Como já mencionado, a técnica CRISPR, devido aos seus inusitados alcances, múltiplas e variadas aplicações, para os seres humanos bem como para os vegetais, animais ou microrganismos, requer avaliações éticas e jurídicas (BERGEL, 2017). Os modelos de governança com base na regulação posterior ao fato, próprios do sistema do Direito, já não são suficientes frente à imprevisibilidade assumida e o potencial de risco das novas tecnologias. Além disso, a autorregulação voluntária também é contestada e cientistas têm indicado modelos mais inclusivos e orientados para o futuro da governança da ciência. Surge, assim, 
um movimento pela "pesquisa e inovação responsável", que apresenta três princípios de governança para a ciência: i] abrir o debate sobre o que rege a "finalidade da pesquisa e da inovação com o envolvimento de um escopo mais amplo de partes interessadas"; ii] institucionalizar a regulamentação da pesquisa e inovação; iii] redefinir a noção de responsabilidade social da ciência. Assim, discutir amplamente o que significa "ciência responsável" é um dos grandes desafios ligados à responsabilidade e à governança da ciência (RYCHNOVSKÁ, 2016).

Para se discutir questões sobre governança para a pesquisa, inicialmente, deve-se falar da responsabilidade pessoal do investigador, que se encontra formalizada em códigos de ética profissional, regulamentos nacionais e internacionais aplicáveis, além de atos juridicamente vinculativos de políticas. Muitos desses mecanismos, no entanto, já se mostraram insuficientes para identificar o potencial imediato e as implicações ambientais e de saúde pública em longo prazo, porque lhes falta clareza em sua jurisdição, são desafiados pelas características distintivas do gene drives, ou fornecem estruturas insuficientes para o engajamento público.

Uma forma de governança, indicada pela Academies of Sciences, Engineering, and Medicine dos Estados Unidos, atenta para que investigadores, instituições de ensino e pesquisa, instituições financiadoras da pesquisa e entidades profissionais trabalhem em conjunto para incentivar e zelar por melhores práticas e por manter e organizar programas de educação e formação em pesquisa responsável. Os laboratórios de pesquisa financiados pelo Instituto Nacional de Saúde estão sujeitos às diretrizes de biossegurança e à supervisão dos comitês de biossegurança, entretanto existem lacunas e sobreposições regulamentares. (UNITED STATES, 2016).

Jonas tem razão ao argumentar que o grande dilema ético frente à manipulação biológica humana "vai muito além da pura intervenção negativa na prevenção de defeitos hereditários". O ser humano terá que responder pela "possível acusação da descendência contra seus criadores", entretanto os descendentes talvez não encontrem mais nenhum réu "que possa ainda responder pelo ato, nem qualquer meio de reparação", pois os riscos podem ser transgeracionais. O mesmo autor choca ao proferir que "aqui se encontra um espaço para crimes com total impunidade, em relação aos quais os atuais perpetradores - que ficaram no passado - estão a salvo perante suas futuras vítimas". Para o autor, só a consciência desse fato já deveria ser suficiente para "exigir a máxima e escrupulosa cautela em qualquer aplicação do poder crescente da arte biológica sobre o ser humano" (JONAS, 2013, p. 111).

Em torno do sistema CRISPR há uma disputa milionária, que rendeu, em 2015, para as "pesquisadoras Doudna e Charpentier, um prêmio no Life Sciences" de US\$ 3 milhões. Porém há uma disputa jurídica de milhões de dólares nos tribunais americanos por patente técnica entre o cientista chinês Feng Zhang e as duas pesquisadoras americanas. O cientista chinês reivindica a patente técnica alegando "que publicou a descoberta na mesma época". É um mercado bilionário que está se instalando, em que "laboratórios em todo o mundo correm para requisitar o direito de exploração comercial sobre possíveis produtos de CRISPR que ainda não existem". (NOHAMA, 2018, s.p.).

Essa corrida pela exploração comercial do uso de CRISPR em pesquisas em linha germinal é extremamente preocupante diante do fato de ainda não haver regulamentação normativa em nível mundial. Não se está a indicar o não uso da tecnologia, mas, sim, que a pesquisa e o desenvolvimento de soluções de saúde ou produções biotecnológicas para a indústria e agropecuária com o CRISPR devem ser reguladas. $A$ comunidade científica internacional tem demonstrado preocupação em "estabelecer padrões éticos de conduta na pesquisa, como a Declaração de Helsinque (1964), a Declaração Universal sobre o Genoma Humano e os Direitos Humanos (2001), da Declaração Universal sobre Bioética e Direitos Humanos (2005) e da própria Declaração Universal dos Direitos Humanos (1948)", contudo são documentos "apenas recomendativos, de adesão voluntária, de modo que o cumprimento ou não destes dispositivos está subjugado às leis e normas internas dos países, que, em regra, tratam as questões de ética em pesquisa de maneira bastante diversa". (NOHAMA, 2018).

São muitos os desafios éticos e soluções de regulamentação para restringir o uso da técnica CRISPR, o que passa a exigir novas formas de governança que contemplem pesquisa e ciência responsável. Teubner 
(1998, p. 162) chama o sistema do Direito para participar de uma governança global, mas para dar conta desse desafio, pois o sistema do Direito "deve aumentar seus conhecimentos sobre processos, funções e estruturas reais do subsistema social regulando e moldar as respectivas normas de acordo com modelos científicos dos sistemas envolventes". A estratégia deve estar alicerçada na comunicação entre os sistemas do Direito, da Ciência, da Economia e político. Para dar conta desse desafio e de temas emergentes que impactam o ser humano, Teubner (2016, p. 269) argumenta em favor de uma "comunidade internacional" em que os direitos humanos não podem ser limitados pela "relação entre Estado e indivíduo ou pelo setor da política institucionalizada ou tampouco por fenômenos de poder em seu sentido mais amplo" (TEUBNER, 2016, p. 254). O que Teubner (2003, p. 12-13 e 21) sugere é uma "teoria do pluralismo jurídico e uma teoria das fontes do direito, correspondentemente concebida em termos pluralistas", ou seja, uma teoria das fontes do direito tem condições de "identificar fenômenos jurídicos autônomos 'apátridas' (staatenlose Rechtsphänomene) no plano global, mesmo sem o recurso legitimador ao direito estatal (ou interestatal)".

Por fim, tem-se presente a fragmentação das pesquisas na aplicação da técnica CRISPRCas9 (muitas pesquisas são realizadas em parceria por pesquisadores de diferentes países, com legislações e códigos de ética diferentes), o financiamento da pesquisa por atores privados, o mercado bilionário que se avizinha, o qual exigirá da comunidade política internacional esforços gigantescos de autorregulação e fiscalização e, principalmente, disseminação e exigência de uma cultura de responsabilidade da ciência com normas éticas internacionais explícitas, com o controle social de organismos internacionais. A geração presente tem o dever de garantir segurança para as gerações futuras, bem como de resguardar que a tecnologia e a percepção social sejam favoráveis a quem ainda não nasceu, visto que quando nascer talvez não terá mais a quem cobrar uma ética de responsabilidade.

\section{Conclusão}

A modificação genética de dois bebês usando a técnica CRISPR-Cas9, divulgada pelo cientista chinês He Jiankui, em dezembro de 2018, levantou inúmeras discussões éticas sobre a responsabilidade da ciência em manipular a natureza humana. Esse é apenas um exemplo de que pesquisas em linha germinal já estão em curso e envolvem um mercado bilionário que pode tanto ser utilizado para fins de terapia gênica como para decidir quais embriões podem ser descartados, ou, ainda, com dupla utilização relacionada aos interesses da tecnologia em determinado contexto sociocultural.

Cumpre relembrar o problema traçado na introdução deste artigo, qual seja: diante das oportunidades e riscos da tecnologia CRISPR-Cas9 quais seriam os possíveis caminhos jurídicos para a pesquisa e inovação responsável?

Quanto à hipótese traçada inicialmente, pode-se dizer que esta se confirmou, pois há a necessidade de uma governança antecipatória, que deve seguir os caminhos de uma conduta comunicativa transdisciplinar e global para delimitar claramente e regular tecnologias e pesquisas com potencial de risco para o ser humano e usos indevidos de resultados de pesquisa. Portanto, são necessárias novas formas de fiscalização e monitoramento das pesquisas, de responsabilização individual do pesquisador, de responsabilização dos organismos financiadores e de responsabilização do Estado, o que traz profundas implicações para a maneira como a ciência é governada.

O sistema do Direito cedo ou tarde será convocado para se posicionar e ele não tem respostas. Entretanto precisa compreender o dilema da dupla utilização da técnica CRISPRCas9 e participar com os demais sistemas para construir um sistema de governança de riscos.

\section{Referências}

ALONSO, Luis Enrique Echarte. Neurocosmética, transhumanismo y materialismo eliminativo: hacia nuevas formas de eugenesia. Cuadernos de Bioética, Madrid, v. 77, n. 23, p. 37-51, 2012. Disponível em: https://dialnet.unirioja.es/servlet/articulo?codigo=3905740. Acesso em: 14 jul. 2019. 
ARAÚJO, Marcelo. Brasil e o genoma humano, discussões sobre o CRISPR-Cas9. IHU Online, São Leopoldo, n. 489, 18 jul. 2016. Disponível em: http://www.ihuonline.unisinos.br/artigo/6525-o-nascimentode-um-jesus-severino-e-a-vitoria-da-esperanca. Acesso em: 08 jun. 2019.

AREND, Marcela Corso; PEREIRA, Jessica Olivaes; MARKOSKI, Melissa Medeiros. O Sistema CRISPR/Cas9 e a possibilidade de edição genômica para a cardiologia. Arq. Bras. Cardiol., São Paulo, v. 108, n. 1, p. 81-83, jan. 2017. Disponível em: http://www.scielo.br/scielo.php?pid=s0066782x2017000100081\&script=sci_arttext\&tlng=pt. Acesso em: 07 jun. 2019.

BARCELLOS, Jorge. He Jiankui e o bebê geneticamente editado. GaúchaZH, Porto Alegre, 06 dez. 2018. Disponível em: https://gauchazh.clicrbs.com.br/tecnologia/noticia/2018/12/he-jiankui-e-o-bebegeneticamente-editado-cjpd1ihbk0jih01picr0gey1h.html. Acesso em: 11 mar. 2019.

BATISTA, Angelo C.; PACHECO, Luis G. C. Detecting pathogens with Zinc-Finger, TALE and CRISPR- based programmable nucleic acid binding proteins. Journal of Microbiological Methods, Guelph, v. 152, p. 98-104, set. 2018. Disponível em: https://www.sciencedirect.com/science/article/pii/ S0167701218303932. Acesso em: 21 mar. 2019.

BECK, Ulrich. A metamorfose do mundo: novos conceitos para uma nova realidade. Tradução: Maria Luiza X. de A. Borges. Rio de Janeiro: Zahar, 2018.

BERGEL, Salvador Darío. O impacto ético das novas tecnologias de edição genética. Revista Bioética, Brasília, v. 25, n. 3, out./dez. 2017. Disponível em: http://www.scielo.br/scielo.php?script=sci_ arttext\&pid=S1983-80422017000300454\&Ing=en\&nrm=iso\&tIng=pt. Acesso em: 04 abr. 2019.

BROKOWSKI, Carolyn; POLLACK, Marya; POLLACK, Robert. Cutting eugenics out of CRISPR-Cas9. Ethics in Biology, Engineering \& Medicine - An International Journal, [S.I.], v. 6, n. 3-4, p. 263279, 2015.

CORBYN, Zoë. Crispr: is it a goodideato 'upgrade' our DNA?. The Guardian, Londres, 10 maio 2015. Disponível em: https://www.theguardian.com/science/2015/may/10/crispr-genome-editing-dnaupgradetechnology-genetic-disease. Acesso em: 21 mar. 2019.

GOLDIM, José Roberto. Genetics and ethics: a possible and necessary dialogue. Journal of Community Genetics, [S.I.], v. 6, n. 3, p. 193-196, 2015. Disponível em: https://www.ncbi.nlm.nih.gov/pmc/articles/ PMC4524833/. Acesso em: 28 jul. 2020.

GONÇALVES, Giulliana Augusta Rangel; PAIVA, Raquel de Melo Alves. Terapia gênica: avanços, desafios e perspectivas. Einstein, São Paulo, v. 15, n. 3, p. 369-375, 2017. Disponível em: http://www. scielo.br/pdf/eins/v15n3/pt_1679-4508-eins-15-03-0369.pdf. Acesso em: 08 jun. 2019.

HABERMAS, Jürgen. $\mathrm{O}$ futuro da natureza humana: a caminho de uma eugenia liberal?. Tradução: Karina Janinni. São Paulo: Martins Fontes, 2004.

HIRSCH, Francois; IPHOFEN, Ron; KOPORC, Zvonimir. Ethics assessment in research proposals adopting CRISPR technology. Biochemia Medica, Zagreb, v. 29, n. 2, p. 1-8, 2019. Disponível em: https://www.ncbi.nlm.nih.gov/pmc/articles/PMC6559619/. Acesso em: 07 jun. 2020.

JACQUARD, Albert; KAHN, Axel. O futuro não está escrito. Tradução: Miguel Mascarenhas. Lisboa: Instituto Piaget, 2004.

JINEK, Martin et al. A programmable dual-RNA-guided DNA endonuclease in adaptive bacterial immunity. Science, Washington, v. 337, n. 6096, p. 816-821, 2012. Disponível em: https://science.sciencemag.org/ content/337/6096/816. Acesso em: 11 mar. 2019.

JONAS, Hans. Técnica, medicina e ética: sobre a prática do princípio responsabilidade. São Paulo: Paulus, 2013.

LAUXEN, Elis Cristina Uhry; GOLDIM, José Roberto. Intervenções genéticas em seres humanos: aspectos éticos e jurídicos. Barbarói, Santa Cruz do Sul, n. 45, p. 202-226, jul./dez. 2015. Disponível em: https://online.unisc.br/seer/index.php/barbaroi/article/view/6861. Acesso em: 11 mar. 2019. 
$\mathrm{LI}$, Jing-Ru et al. Experiments that led to the first gene-edited babies: the ethical failings and the urgent need for better governance. J Zhejiang Univ Sci B, [S.I.], v. 20, n. 1, p. 32-38, jan. 2019. Disponível em: https://www.ncbi.nlm.nih.gov/pmc/articles/PMC6331330/. Acesso em: 07 jun. 2020.

MARÇAL, Anderson Carlos; AMORIM, Laura Lúcia da Silva. Técnica de engenharia genética "agrupamento de curtas repetições palindrômicas regularmente interespaçadas associadas ao sistema CAS" (CRISPR/CAS) e as suas relações com as leis nacionais e internacionais. Revista de Biodireito e Direitos dos Animais, Florianópolis, v. 3, n. 2, p. 57-77, jul./dez. 2017. Disponível em: https://www. indexlaw.org/index.php/revistarbda/article/view/. Acesso em: 21 mar. 2019.

MCCONNELL, Sean C.; BLASIMME, Alessandro. Ethics, values, and responsibility in human genome editing. AMA Journal of Ethics, Illinois, v. 21, n. 12, p. 1017-1020, dec. 2019. Disponível em: https:// journalofethics.ama-assn.org/sites/journalofethics.ama-assn.org/files/2019-11/fred1-1912_0.pdf. Acesso em: 08 jun. 2020.

NOHAMA, Norton. CRISPR: entre a esperança e a agonia. Revista IHU ON-LINE, São Leopoldo, 06 dez. 2018. Disponível em: http://www.ihu.unisinos.br/78-noticias/585255-crispr-entre-a-esperanca-e-a-agonia. Acesso em: 15 jul. 2019.

ORGANIZAÇÃO DAS NAÇÕES UNIDAS PARA A EDUÇÃO, A CIÊNCIA E A CULTURA. Declaração universal sobre o genoma humano e os direitos humanos: da teoria à prática. Brasília: UNESCO, 2001. Disponível em: https://unesdoc.unesco.org/ark:/48223/pf0000122990_por. Acesso em: 04 abr. 2019.

PARLAMENTO EUROPEU. Direção-Geral dos Serviços de Estudos do Parlamento Europeu (DG EPRS). Unidade da Prospetiva Científica (STOA). Mais dez tecnologias suscetíveis de transformar as nossas vidas: análise aprofundada. Bruxelas, jul. 2017. Disponível em: http://www.europarl.europa.eu/doceo/ document/TA-8-2017-0051_PT.html?redirect. Acesso em: 09 jun. 2019.

PASSOS, Geraldo Aleixo Passos et al. Aplicação e Técnica. In: PEREIRA, Tiago Campos (org.). Introdução à Técnica CRISPR. Ribeirão Preto: Sociedade Brasileira de Genética, 2016. p. 71-843. Disponível em: https://www.sbg.org.br/sites/default/files/livro_introducao_a_tecnica_de_crispr_1.pdf. Acesso em: 29 jul. 2020.

REGALADO, Antonio. Exclusive: chinese scientists are creating CRISPR babies. MIT Technology Review, Cambridge, 25 nov. 2018. Disponível em: https://www.technologyreview.com/s/612458/exclusivechinese-scientists-are-creating-crispr-babies/. Acesso em: 07 jun. 2019.

ROMÁN, Javier Correa. CRISPR/Cas9 y el abismo de un nuevo ciclo Interdisciplinar. Ensayos de Filosofía, Granada, n. 6, semestre 2, 2017. Disponível em: http://www.ensayos-filosofia.es/archivos/ articulo. Acesso em: 12 jul. 2019.

RYCHNOVSKÁ, Dagmar. Governing dual-use knowledge: from the politics of responsible science to the ethicalization of security. Security Dialogue, [S.I.], v. 47, n. 4, p. 310-328, 2016. Disponível em: https:// journals.sagepub.com/doi/10.1177/0967010616658848. Acesso em: 05 jun. 2020.

SANTOS, Sandna Larissa Freitas et al. CRISPR: uma nova era na biologia molecular. Revista Biotecnologia \& Ciência, Anápolis, v. 5, n. 2, p. 40-48, 2016. http://www.revista.ueg.br/index.php/ biociencia/article/view/5756t. Acesso em: 04 abr. 2019.

SCHOKRPUR, Shiruyeh et al. CRISPR-Mediated VHL knockout generates an improved model for metastatic renal cell carcinoma. Scientific Reports, [S.I.], v. 6, n. 29032, 2016. Disponível em: https:// www.nature.com/articles/srep29032. Acesso em: 21 mar. 2019.

SUGARMAN, Jeremy. Ethics and germline gene editing. EMBO Reports, [S.I.], v. 16, n. 8, p. 879-880, aug. 2015. Disponível em: https://www.ncbi.nlm.nih.gov/pmc/articles/PMC4552475/. Acesso em: 08 jun. 2020.

TEUBNER, Gunther. O direito como sistema autopoiético. Lisboa: Fundação Calouste Gulbenkian, 1989.

TEUBNER, Gunther. A bukowina global sobre a emergência de um pluralismo jurídico transnacional. Impulso, Piracicaba, n. 14, v. 33, p. 9-31, 2003.

TEUBNER, Gunther. Fragmentos constitucionais: constitucionalismo social na globalização. São Paulo: Saraiva, 2016. 
UNITED STATES. The National Academies of Sciences, Engineering, and Medicine. Gene Drives on the Horizon: Advancing Science, Navigating Uncertainty, and Aligning Research with Public Values. Board on Life Sciences, Washington, jun. 2016. Disponível em: http://dels.nas.edu/bls. Acesso em: 15 jul. 2019.

WANG, Kevin. CRISPR and the future of genome engineering: a bold new world. Intersect: The Stanford Journal of Science, Technology, and Society, Stanford, v. 10, n. 3, p. 1-11, 2017. Disponível em: http:// ojs.stanford.edu/ojs/index.php/intersect/article/view/1019. Acesso em: 11 jun. 2019.

$\mathrm{XU}$, MengMeng. CCR5- $\triangle 32$ biology, gene editing, and warnings for the future of CRISPR-Cas 9 as a human and humane gene editing tool. Cell \& Bioscience, [S.I.], v. 10, mar. 2020. Disponível em: https:// www.ncbi.nlm.nih.gov/pmc/articles/PMC7106751/. Acesso em: 07 jun. 2020.

Recebido em: 15/07/2019

Aprovado em: 20/11/2019 